\title{
Synthesis of Sulfated Cyclodextrin Amphiphiles with Liposomal Encapsulation Properties
}

\author{
Tetsuya Furuike*, Koichi Nasu, Hiroshi Tamura \\ Faculty of Chemistry, Materials and Engineering, Kansai University, Suita, Japan \\ Email: ${ }^{*}$ furuike@kansai-u.ac.jp
}

Received 24 July 2015; accepted 29 August 2015; published 1 September 2015

Copyright (C) 2015 by authors and Scientific Research Publishing Inc.

This work is licensed under the Creative Commons Attribution International License (CC BY).

http://creativecommons.org/licenses/by/4.0/

(c) (i) Open Access

\section{Abstract}

A novel class of amphiphiles with sulfate groups at the C-6 position and palmitoyl groups at the C-2, 3 positions of $\alpha$-, $\beta$-, and $\gamma$-cyclodextrin (CD) were efficiently synthesized. These compounds formed stable monolayers with high collapse pressures at the air-water interface. The mixed monolayer behaviors of the 6-O-sulfated $\mathrm{CD}$ amphiphiles $\left(\mathrm{SO}_{3}-\mathrm{CDC}_{16}\right)$ in the presence of dipalmitoyl phosphatidylcholine (DPPC) and cholesterol were discussed using the surface pressure-molecular area $(\pi-A)$ isotherms. The collapse pressures showed maxima at molar ratios of $\mathrm{SO}_{3}-\mathrm{CDC}_{16}$ lower than $10 \mathrm{~mol} \%$. A morphological analysis of the liposomes containing DPPC and $4 \mathrm{~mol} \% \mathrm{SO}_{3}-\mathrm{CDC}_{16}$ formed in PBS was carried out using transmission electron microscopy with negative staining, and vesicles with maximum diameters of $350-500 \mathrm{~nm}$ were observed. Moreover, the releasing ability of these liposomes was examined using a fluorescent compound, calcein. It was clearly shown that liposomes containing $\mathrm{SO}_{3}-\mathrm{CDC}_{16}$ could release encapsulated calcein more easily than liposomes consisting only of DPPC, and that the release rate depended on the phase transition temperature of the $\mathrm{SO}_{3}-\mathrm{CDC}_{16}$ included in the liposome membrane.

\section{Keywords}

Cyclodextrin, Amphiphile, Liposome, Encapsulation

\section{Introduction}

$\alpha$-, $\beta$-, and $\gamma$-cyclodextrins (CDs) are cyclic oligosaccharides consisting of six, seven, and eight D-glucopyranose residues, respectively, which are linked by $\alpha-1,4$ glycosidic bonds to form macrocycles. CDs have a hydrophilic

${ }^{*}$ Corresponding author.

How to cite this paper: Furuike, T., Nasu, K. and Tamura, H. (2015) Synthesis of Sulfated Cyclodextrin Amphiphiles with Liposomal Encapsulation Properties. Journal of Encapsulation and Adsorption Sciences, 5, 144-154. 
outer surface and a hydrophobic central cavity and have the ability to form inclusion complexes with specific guests. Therefore, CDs have the potential to alter the physical, chemical, and biological properties of various organic compounds [1]-[3]. The most common pharmaceutical application of CDs is to improve the solubility, stability, and bioavailability of various hydrophobic drugs [4]. However, natural CDs have relatively low solubility in both water and organic solvents, thus limiting their use in pharmaceutical formulations. Recently, various kinds of CD derivatives have been prepared to extend the physicochemical properties and inclusion capacity of natural CDs as novel drug carriers [5] [6]. Many researchers have synthesized CD derivatives bearing saccharides, which are used to target sugar recognition molecules and improve drug delivery capability, and which are expected to have a glycoside cluster effect [7]-[14]. However, the high external hydrophilicity of these CD derivatives results in a lack of affinity of the CD-based supramolecules with biological membranes. This problem is one of the reasons why researchers have been interested in CD derivatives with a relatively hydrophobic exterior. As a result, CD derivatives with increased affinity for biological membranes have been obtained by introducing fatty acids onto the hydroxyl groups of CDs. Thus, it is suggested that drug delivery to organs, tissues, and cells could become sufficiently possible. Such amphiphilic CDs have been prepared by grafting hydrocarbon chains on the hydroxyl groups of $\alpha$-, $\beta$-, or $\gamma$-CD. For example, a Medusa-like CD was obtained by grafting hydrophobic groups onto all the primary hydroxyl groups of a $\beta$-CD [15]-[19]. Skirt-shaped CDs were obtained corresponding to esterification or alkylation of all the secondary hydroxyl groups [20] [21]. These various CD derivatives do not differ only in the position and length of the alkyl chains, but also in the nature of the chemical bond.

The monolayer behaviors of synthetic CD amphiphiles have been studied at the air-water interface [22]-[28]. The surface pressure-molecular area $(\pi-A)$ isotherms of the monolayers disclose the size of the molecules, as well as the stability and phase behaviors of the monolayer films. The miscibility of mixed monolayers composed of two lipids with various concentration ratios can be elucidated from the $\pi-A$ isotherms. A correspondence between the ideal line and a plot of molecular area at a fixed surface pressure versus the molar fraction of two lipids shows complete miscibility, whereas deviation from the ideal line represents partial miscibility. Liposomes are artificial cell-like materials and have been considered as a strong candidate for a drug delivery carrier [29][33]. Drug delivery carriers are required to keep drugs inside their vehicle while traveling through the blood stream and to release the drugs after binding to the target cell.

In a previous paper, we reported the synthesis of 6-O-sulfated $\mathrm{CD}$ amphiphiles $\left(\mathrm{SO}_{3}-\mathrm{CDC}_{16}\right)$ and preliminary data on the formation of liposomes containing these CD derivatives [34]. Herein, the miscibility of monolayers composed of $\mathrm{SO}_{3}-\mathrm{CDC}_{16}$ with dipalmitoyl phosphatidylcholine (DPPC) and cholesterol was investigated in detail. Moreover, the formation of these liposomes was confirmed by transition electron microscopy (TEM) using negative staining. To test the encapsulation ability of the liposomes, 3,3'-bis [ $N, N$-bis(carboxymethyl) aminomethyl]fluoroscein (calcein), an anionic dye was captured in the liposomes and changes in fluorescence intensity were used to monitor the time dependence of dye leakage.

\section{Experimental}

\subsection{Materials and Methods}

Unless otherwise stated, all commercially available solvents and reagents were used without further purification. ${ }^{1} \mathrm{H}$ - and ${ }^{13} \mathrm{C}$-NMR were recorded at $600 \mathrm{MHz}$ or $150 \mathrm{MHz}$ on a BRUKER 600 spectrometer. Assignment of the ring-protons was made by first-order analysis of the spectra, and was confirmed by H-H COSY and HMQC spectra. Elemental analyses were performed with a Yanako CHN recorder MT-6. Optical rotations were determined with a Perkin-Elmer 241 polarimeter for samples in a $10 \mathrm{~cm}$ cell at ambient temperature $\left(22^{\circ} \mathrm{C} \pm 2{ }^{\circ} \mathrm{C}\right)$. Fluorescent measurements were carried out with a Perkin-Elmer Luminescence spectrometer LS-50B. Transmission Electron Microscope (TEM) images were obtained using JEOL JEM-1210 after negative straining with uranyl acetate. Differential Scanning Calorimetry (DSC) was recorded at a Perkin-Elmer DSC 6000. Each sample was heated from $10^{\circ} \mathrm{C}$ to $80^{\circ} \mathrm{C}$ with at a heating rate of $5^{\circ} \mathrm{C} / \mathrm{min}$. Chemical reactions were monitored by thinlayer chromatography (TLC) on precoated plates of silica gel 60F254 (layer thickness, $0.25 \mathrm{~mm}$; E. Merck, Darmstadt). Column chromatography was performed on silica gel (Silica gel 60; $0.015-0.040 \mathrm{~mm}$, E. Merck).

Hexakis (6-O-tert-butyldimethylsilyl-2,3-di-O-palmitoyl) cyclomaltohexaose (4) A solution of palmitoyl anhydride $(10.74 \mathrm{~g}, 21.70 \mathrm{mmol})$ in dry pyridine $(150 \mathrm{~mL})$ was stirred with 4-dimethylaminopyridine $(1.33 \mathrm{~g}$, $10.85 \mathrm{mmol})$ and silylated $\alpha$-cyclodextrin $1(1.50 \mathrm{~g}, 0.904 \mathrm{mmol})$ at $80^{\circ} \mathrm{C}$ for $48 \mathrm{~h}$ under $\mathrm{N}_{2}$ atmosphere then cooled at room temperature. The mixture was concentrated under reduced pressure. The obtained residue was 
dissolved with n-hexane, and chromatographed repeatedly to remove an excess fatty acid, eluting with n-hexane-tert-butyl methyl ether 30:1 to give 4 (3.30 g, 81\%); $\mathrm{R} f 0.35$ (hexane:t-butyl methyl ether $=30: 1$ ); $[\alpha]_{\mathrm{D}}=$ $+25.8^{\circ}\left(\mathrm{c}_{0.424}, \mathrm{CHCl}_{3}\right) ;{ }^{1} \mathrm{H}-\mathrm{NMR}\left(\mathrm{CDCl}_{3}\right) \delta 5.51\left(\mathrm{t}, 6 \mathrm{H}, J_{3,4} 8.9 \mathrm{~Hz}, \mathrm{H}-3 \times 6\right), 5.05\left(\mathrm{~d}, 6 \mathrm{H}, J_{1,2} 3.1 \mathrm{~Hz}, \mathrm{H}-1 \times 6\right)$, 4.62 (dd, $\left.6 \mathrm{H}, J_{2,3} 10.3 \mathrm{~Hz}, \mathrm{H}-2 \times 6\right), 4.10$ (d, 6H, $J_{6 \mathrm{a}, 6 \mathrm{~b}} 10.6 \mathrm{~Hz}, \mathrm{H}-6 \mathrm{a} \times 6$ ), 3.99 (t, 6H, $\left.J_{4,5} 9.0 \mathrm{~Hz}, \mathrm{H}-4 \times 6\right), 3.83$ (d, 6H, J5,6 $9.3 \mathrm{~Hz}, \mathrm{H}-5 \times 6), 3.65$ (d, 6H, H-6b × 6), 2.32-2.15 (m, 24H, -COCH $\left.2^{-} \times 12\right), 1.55-1.51(\mathrm{~m}, 24 \mathrm{H}$, $\left.-\mathrm{CH}_{2^{-}} \times 12\right), 1.27\left(\mathrm{~s}, 288 \mathrm{H},-\mathrm{CH}_{2^{-}} \times 144\right), 0.87-0.84\left(\mathrm{~m}, 90 \mathrm{H},-\mathrm{CH}_{3} \times 12\right.$ and $\left.t \mathrm{Bu} \times 6\right)$ and $0.02(\mathrm{~d}, 36 \mathrm{H}$, $\left.-\left(\mathrm{CH}_{3}\right)_{2} \mathrm{Si}-\times 6\right) ;{ }^{13} \mathrm{C}-\mathrm{NMR}\left(\mathrm{CDCl}_{3}\right) \delta 171.1,169.8,97.0,75.7,72.6,72.3,71.7,62.3,26.2,21.3,21.1,18.7,-4.6$ and -4.9; Anal. Calcd for $\mathrm{C}_{264} \mathrm{H}_{504} \mathrm{O}_{42} \mathrm{Si}_{6}$ : C, 70.16; H, 11.24. Found: C, 70.47; H, 11.47.

Heptakis (6-O-tert-butyldimethylsilyl-2,3-di-O-palmitoyl) cyclomaltoheptaose (5) A solution of palmitoyl anhydride (10.74 g, $21.70 \mathrm{mmol})$ in dry pyridine $(150 \mathrm{~mL})$ was stirred with 4-dimethylaminopyridine (1.33 g, $10.85 \mathrm{mmol})$ and silylated $\beta$-cyclodextrin 2 (1.50 g, $0.775 \mathrm{mmol})$. The reaction mixture was stirred for $48 \mathrm{~h}$ at $80^{\circ} \mathrm{C}$, then compound 5 (3.50 g, 86\%) was given according to same procedure as described in 4; Rf 0.33 (hexane:t-butyl methyl ether $=30: 1) ;[\alpha]_{\mathrm{D}}=+46.5^{\circ}\left(\mathrm{c} 0.372, \mathrm{CHCl}_{3}\right) ;{ }^{1} \mathrm{H}-\mathrm{NMR}\left(\mathrm{CDCl}_{3}\right) \delta 5.34\left(\mathrm{t}, 7 \mathrm{H}, J_{3,4} 9.0 \mathrm{~Hz}\right.$, H-3 × 7), 5.09 (d, 7H, $J_{1,2} 3.6$ Hz, H-1 × 7), 4.64 (dd, 7H, $J_{2,3} 10.2 \mathrm{~Hz}, \mathrm{H}-2 \times 7$ ), 4.03 (d, 7H, $J_{5,6} 10.8 \mathrm{~Hz}, \mathrm{H}-6 \mathrm{a}$ $\times 7), 3.83(\mathrm{~m}, 14 \mathrm{H}, \mathrm{H}-4 \times 7$ and $\mathrm{H}-5 \times 7), 3.67\left(\mathrm{~d}, 7 \mathrm{H}, J_{5,6} 10.8 \mathrm{~Hz}, \mathrm{H}-6 \mathrm{~b} \times 7\right), 2.33-2.14\left(\mathrm{~m}, 28 \mathrm{H},-\mathrm{COCH}_{2}-\times\right.$ 14), $1.52-1.23\left(\mathrm{~m}, 336 \mathrm{H},-\mathrm{CH}_{2^{-}} \times 168\right), 0.85\left(\mathrm{~m}, 105 \mathrm{H},-\mathrm{CH}_{3} \times 14\right.$ and $\left.t \mathrm{Bu} \times 7\right)$ and $0.01\left(\mathrm{~m}, 42 \mathrm{H},-\left(\mathrm{CH}_{3}\right)_{2} \mathrm{Si}-\times\right.$ 7); ${ }^{13} \mathrm{C}-\mathrm{NMR}\left(\mathrm{CDCl}_{3}\right) \delta 173.3,172.1,96.2,75.6,72.3,71.6,71.3,62.4,32.3,30.2-29.8,26.3,25.2,23.1,14.4$ and -4.6; Anal. Calcd for $\mathrm{C}_{308} \mathrm{H}_{588} \mathrm{O}_{49} \mathrm{Si}_{7}$ : C, 70.16; H, 11.24. Found: C, 69.97; H, 11.29.

Octakis (6-O-tert-butyldimethylsilyl-2,3-di-O-palmitoyl) cyclomaltooctaose (6) A solution of palmitoyl anhydride (10.74 g, $21.70 \mathrm{mmol})$ in dry pyridine $(150 \mathrm{~mL})$ was stirred with 4-dimethylaminopyridine (1.33 g, $10.85 \mathrm{mmol})$ and silylated $\gamma$-cyclodextrin 3 (1.50 g, $0.678 \mathrm{mmol})$. The compound 6 (3.70 g, 91\%) was given according to same procedure as described in 4; Rf 0.32 (hexane:t-butyl methyl ether $=30: 1$ ); $[\alpha]_{\mathrm{D}}=+55.0^{\circ}(\mathrm{c}$ 0.334, CHCl3); ${ }^{1} \mathrm{H}-\mathrm{NMR}\left(\mathrm{CDCl}_{3}\right) \delta 5.33$ (brd, 8H, H-3 × 8), 5.18 (brd, 8H, H-1 × 8), 4.59 (brd, $8 \mathrm{H}, \mathrm{H}-2 \times 8$ ), 4.02 (brd, $8 \mathrm{H}, \mathrm{H}-6 \mathrm{a} \times 8), 3.69$ (m, 24H, H-4 × 8, H-5 × 8 and H-6b × 8), $2.32-2.13\left(\mathrm{~m}, 32 \mathrm{H},-\mathrm{COCH}_{2^{-}} \times 16\right)$, $1.54\left(\mathrm{~m}, 32 \mathrm{H},-\mathrm{CH}_{2^{-}} \times 16\right), 1.27-1.23\left(\mathrm{~m}, 384 \mathrm{H},-\mathrm{CH}_{2^{-}} \times 192\right), 0.85\left(\mathrm{~m}, 120 \mathrm{H},-\mathrm{CH}_{3} \times 16\right.$ and $\left.t \mathrm{Bu} \times 8\right)$ and $0.01\left(\mathrm{~m}, 48 \mathrm{H},-\left(\mathrm{CH}_{3}\right)_{2} \mathrm{Si}-\times 8\right) ;{ }^{13} \mathrm{C}-\mathrm{NMR}\left(\mathrm{CDCl}_{3}\right) \delta 173.3,172.1,96.5,72.3-71.8,62.2,32.4,30.4-29.8,26.3$, 25.2, 23.114 .5 and -4.6; Anal. Calcd for $\mathrm{C}_{352} \mathrm{H}_{672} \mathrm{O}_{56} \mathrm{Si}_{8}$ : C, 70.16; H, 11.24. Found: C, 70.11; H, 11.33.

Hexakis (2,3-di-O-palmitoyl) cyclomaltohexaose (7) A solution of 4 (50 mg, $11.1 \mu \mathrm{mol})$ in dichloromethane $(5.0 \mathrm{~mL})$ was added $\mathrm{BF}_{3} \cdot \mathrm{Et}_{2} \mathrm{O}(9.80 \mu \mathrm{L}, 79.7 \mu \mathrm{mol})$. The mixture was stirred under nitrogen atmosphere at room temperature for $2 \mathrm{~h}$, and evaporated under reduced pressure. Silyl compounds as by-products and boron trifluoride as reagent was removed by evaporation under reduced pressure, because they don't have a high boiling point. Desired compound 7 was given without purification because of unstable, then immediately was performed a sulfated reaction; ${ }^{1} \mathrm{H}-\mathrm{NMR}\left(\right.$ Pyridine- $\left.d_{5}\right) \delta 6.01$ (t, $6 \mathrm{H}, J_{3,4} 6.0 \mathrm{~Hz}, \mathrm{H}-3 \times 6$ ), 5.72 (brd, 6H, H-1 × 6), 5.52 (brd, $6 \mathrm{H}, \mathrm{OH} \times 6) 5.31$ (d, 6H, J2,3 $12.0 \mathrm{~Hz}, \mathrm{H}-2 \times 6$ ), 4.66 (brd, 6H, H-5 × 6), 4.62 (brd, 6H, H-4 × 6), 4.55 (brd, $6 \mathrm{H}$, H-6a × 6), 4.48 (brd, 6H, H-6b × 6), $2.69-2.56$ (m, 24H, $\left.-\mathrm{COCH}_{2^{-}} \times 12\right), 1.86$ (brd, $\left.24 \mathrm{H},-\mathrm{CH}_{2^{-}} \times 12\right), 1.50-$ 1.27 (brd, $288 \mathrm{H},-\mathrm{CH}_{2} \times 144$ ), and 0.94 (brd, $36 \mathrm{H},-\mathrm{CH}_{3} \times 12$ ).

Heptakis (2,3-di-O-palmitoyl) cyclomaltoheptaose (8) A solution of 5 (100 mg, $19.0 \mu \mathrm{mol})$ in dichloromethane $(1.0 \mathrm{~mL})$ was added $\mathrm{BF}_{3} \cdot \mathrm{Et}_{2} \mathrm{O}(23.3 \mu \mathrm{L}, 189.7 \mu \mathrm{mol})$. The mixture was stirred for $2 \mathrm{~h}$ at room temperature, diluted with dichloromethane, and poured into ice water. The organic layer was separated, washed successively with water, aqueous sodium hydrogen carbonate, and brine, dried, and concentrated. The residue was purified by gel-filtrated with Sephadex LH-20 to give 8 (72 mg, 85\%); $[\alpha]_{\mathrm{D}}=+42.9^{\circ}\left(\mathrm{c} 0.313, \mathrm{CHCl}_{3}\right) ;{ }^{1} \mathrm{H}-\mathrm{NMR}\left(\mathrm{CDCl}_{3}\right) \delta$ 5.30 (brd, 7H, H-3 × 7), 5.06 (brd, 7H, H-1 × 7), 4.71 (brd, 7H, H-2 × 7), 3.96 (brd, 14H, H-5 × 7 and H-6a $\times 7$ ), 3.85 (brd, 7H, H-6b × 7), 3.69 (brd, 7H, H-4 × 7), 2.28-2.13 (m, 28H, $\left.-\mathrm{COCH}_{2^{-}} \times 14\right), 1.52\left(\mathrm{brd}, 28 \mathrm{H},-\mathrm{CH}_{2^{-}} \times\right.$ 14), 1.23 (brd, $\left.336 \mathrm{H},-\mathrm{CH}_{2^{-}} \times 168\right)$ and 0.85 (brd, $\left.42 \mathrm{H},-\mathrm{CH}_{3} \times 14\right) ;{ }^{13} \mathrm{C}-\mathrm{NMR}\left(\mathrm{CDCl}_{3}\right) \delta 173.8,173.2,96.5$, 76.0, 72.7, 71.7, 61.6, 34.5, 34.3, 32.4, 30.3 - 29.7, 25.4, 25.2, 23.1 and 14.5; Anal. Calcd for $\mathrm{C}_{266} \mathrm{H}_{490} \mathrm{O}_{49}$ : C, 71.43; H, 11.04. Found: C, 71.35; H, 11.16 .

Octakis (2,3-di-O-palmitoyl) cyclomaltooctaose (9) A solution of 6 (150 mg, $24.9 \mu \mathrm{mol})$ in dichloromethane $(2.0 \mathrm{~mL})$ was added $\mathrm{BF}_{3} \cdot \mathrm{Et}_{2} \mathrm{O}(30.6 \mu \mathrm{L}, 248.9 \mu \mathrm{mol})$, then compound 9 was given according to same procedure as described in 8 (120 mg, 94\%); $[\alpha]_{\mathrm{D}}=+45.7^{\circ}(\mathrm{c} 0.299, \mathrm{CHCl} 3) ;{ }^{1} \mathrm{H}-\mathrm{NMR}\left(\mathrm{CDCl}_{3}\right) \delta 5.32(\mathrm{brd}, 8 \mathrm{H}, \mathrm{H}-3$ $\times$ 8), 5.09 (s, 8H, H-1 × 8), 4.68 (d, 8H, H-2 × 8), 3.85 (brd, 32H, H-4 × 8, H-5 × 8, H-6a $\times 8$ and H-6b $\times 8$ ), $2.31-2.12$ (m, 32H, $\left.-\mathrm{COCH}_{2^{-}} \times 16\right), 1.52$ (brd, 32H, $\left.-\mathrm{CH}_{2^{-}} \times 16\right), 1.23$ (brd, 384H, $-\mathrm{CH}_{2^{-}} \times 192$ ) and 0.85 (brd, $\left.48 \mathrm{H},-\mathrm{CH}_{3} \times 16\right) ;{ }^{13} \mathrm{C}-\mathrm{NMR}\left(\mathrm{CDCl}_{3}\right) \delta 173.7,172.2,96.5,72.7,71.2,61.2,34.5,32.4,30.3-29.7,25.1,23.1$ and 14.5. Anal. Calcd for $\mathrm{C}_{304} \mathrm{H}_{560} \mathrm{O}_{56}$ : C, 71.43; H, 11.04. Found: C, 71.27; H, 11.12 .

Hexakis (2,3-di-O-palmitoyl-6-O-sulfo) cyclomaltohexaose, hexakis (trimethylamine) salts (10) A solu- 
tion of 7 (40 mg, $10.43 \mu \mathrm{mol})$ and sulfur trioxide-trimethylamine complex (87.1 mg, 0.626 mmol) in toluene and DMF (total $2.0 \mathrm{~mL}$ ) was stirred for $48 \mathrm{~h}$ at $100^{\circ} \mathrm{C}$, then cooled. Methanol was added, and the mixture was concentrated. The residue was eluted from a column of Sephadex LH-20 with 2:1 chloroform-methanol to give 10 (42 mg, 86\%); $[\alpha]_{\mathrm{D}}=+30.9^{\circ}\left(\mathrm{c} 0.332, \mathrm{CHCl}_{3}\right) ;{ }^{13} \mathrm{C}-\mathrm{NMR}\left(\mathrm{CDCl}_{3}\right) \delta 173.6,173.0,98.2,72.0,71.1,70.2,66.5$, 46.0, 36.1, 34.6, 32.4, 30.3 - 29.8, 25.2, 23.1 and 14.5; Anal. Calcd for $\mathrm{C}_{246} \mathrm{H}_{474} \mathrm{~N}_{6} \mathrm{O}_{60} \mathrm{~S}_{6} \cdot 9 \mathrm{H}_{2} \mathrm{O}: \mathrm{C}, 61.16$; H, 10.27; N, 1.74; S, 3.98. Found: C, 61.14; H, 10.15; N, 1.59; S, 3.91. Phase transition temperature (DSC): $41.0^{\circ} \mathrm{C}$.

Heptakis (2,3-di-O-palmitoyl-6-O-sulfo) cyclomaltoheptaose, heptakis (trimethylamine) salts (11) A solution of $8(80 \mathrm{mg}, 17.89 \mu \mathrm{mol})$ and sulfur trioxide-trimethylamine complex $(174 \mathrm{mg}, 1.25 \mathrm{mmol})$ in toluene and DMF (total $2.0 \mathrm{~mL}$ ) was stirred for $48 \mathrm{~h}$ at $80^{\circ} \mathrm{C}$ then compound $11(81 \mathrm{mg}, 83 \%)$ was given according to same procedure as described in 10; $[\alpha]_{\mathrm{D}}=+38.0^{\circ}\left(\mathrm{c} 0.296, \mathrm{CHCl}_{3}\right) ;{ }^{13} \mathrm{C}-\mathrm{NMR}\left(\mathrm{CDCl}_{3}\right) \delta 172.8,96.3,75.0,70.6,70.0$, 66.3, 45.6, 34.6, 34.2, 34.0, 32.0, 29.9 - 29.4, 27.1, 24.7, 22.7 and 14.1; Anal. Calcd for $\mathrm{C}_{287} \mathrm{H}_{553} \mathrm{~N}_{7} \mathrm{O}_{70}$ $\mathrm{S}_{7} \cdot 3.5 \mathrm{H}_{2} \mathrm{O}$ : C, 62.56; H, 10.11; N, 1.78; S, 4.07. Found: C, 62.77; H, 10.10; N, 1.67; S, 4.04. Phase transition temperature (DSC): $37.2^{\circ} \mathrm{C}$.

Octakis (2,3-di-O-palmitoyl-6-O-sulfo) cyclomaltooctaose, octakis (trimethylamine) salts (12) A solution of $9(100 \mathrm{mg}, 19.56 \mu \mathrm{mol})$ and sulfur trioxide-trimethylamine complex (217 mg, $1.56 \mathrm{mmol})$ in toluene and DMF (total $2.0 \mathrm{~mL}$ ) was stirred for $48 \mathrm{~h}$ at $80^{\circ} \mathrm{C}$, then compound 12 (110 $\left.\mathrm{mg}, 90 \%\right)$ was given according to same procedure as described in 10; $[\alpha]_{\mathrm{D}}=+46.5^{\circ}\left(\mathrm{c} 0.298, \mathrm{CHCl}_{3}\right) ;{ }^{13} \mathrm{C}-\mathrm{NMR}\left(\mathrm{CDCl}_{3}\right) \delta 173.2,96.7,70.7,66.3$, 45.9, 34.6, 32.3, 30.2-29.8, 25.1, 23.0 and 14.4; Anal. Calcd for $\mathrm{C}_{328} \mathrm{H}_{632} \mathrm{~N}_{8} \mathrm{O}_{80} \mathrm{~S}_{8} \cdot 4 \mathrm{H}_{2} \mathrm{O}$ : C, 62.56; H, 10.23; N, 1.78; S, 4.07. Found: C, 62.83; H, 10.16; N, 1.75; S, 4.03. Phase transition temperature (DSC): $36.6^{\circ} \mathrm{C}$.

\subsection{Surface Pressure-Molecular Area Isotherms for Monomolecular Layers}

The $\pi-A$ isotherms for monomolecular layers were obtained from experiments performed on a Langmuir-type film balance. The water subphase was obtained through reverse osmosis using a Milli-Ro Plus 3 water purification system (Millipore, USA). A mixture of DPPC and cholesterol containing 0 - 100 mol\% SO $_{3}-C_{16}$ 10-12 was spread at the air-water interface from mixed chloroform solutions $(0.2 \mathrm{mg} / \mathrm{mL})$ by using a microsyringe (Hamilton). After complete evaporation of the organic solvent, the measurement was performed using a Langmuir-type film balance (U.S.I., Japan) located at the air-water interface at $23^{\circ} \mathrm{C}$. The temperature was controlled by a thermostated bath. The monolayers were compressed at a rate of $60 \mathrm{~mm}^{2} / \mathrm{min}$. The $\pi$ - $A$ isotherms were determined at least three times.

\subsection{Preparation of Liposomes by Reverse-Phase Evaporation}

$\mathrm{SO}_{3}-\mathrm{CDC}_{16}$ 10-12 in diethyl ether was added to a $25 \mathrm{~mL}$ round-bottom flask with a cap, and the solvent was removed under reduced pressure. The amphiphile was redissolved in diethyl ether, and pure water was added to the solution for the formation of reverse-phase vesicles (diethyl ether:water $=3: 1, \mathrm{v} / \mathrm{v}$ ). The resulting two-phase system was briefly sonicated in a bath-type sonicator (NEY 28H, USA: $120 \mathrm{~W}, 45 \mathrm{kHz}$ ) under a nitrogen atmosphere until the mixture forms a homogeneous opalescent dispersion. Liposomes consisting of only $\mathrm{SO}_{3}$ $\mathrm{CDC}_{16}$ were purified by column chromatography on a Sephadex G-50 column $(30 \mathrm{~cm} \times 1.5 \mathrm{~cm}$ i.d. $)$ and eluted with pure water.

DPPC and cholesterol were added to $\mathrm{SO}_{3}-\mathrm{CDC}_{16}$ to increase the stability of the liposomes. The mole ratio of DPPC, cholesterol, and $\mathrm{SO}_{3}-\mathrm{CDC}_{16}$ 10-12 in the liposomes was 100:10:4. The amphiphilic mixtures dissolved in dichloromethane were put into a $25 \mathrm{~mL}$ round-bottom flask, and phosphate buffered saline (PBS, pH 7.4) solution was added in the absence or presence of calcein $(0.1 \mathrm{mM})$ (dichloromethane:PBS = 3:1). The mixtures underwent ultrasonication for 5 min until they formed a homogeneous opalescent dispersion. In these suspensions, which were used to form reverse-phase vesicles, dichloromethane was gently removed with a rotary evaporator under reduced pressure. As the majority of the solvent was removed, the material first formed a viscous gel. After destruction of the gel using a vortex mixer for $1 \mathrm{~min}$, dichloromethane was removed completely from the mixture to give a liposome solution. The desired liposomes were separated by column chromatography on a Sephadex G-50 column (30 $\mathrm{cm} \times 1.5 \mathrm{~cm}$ i.d.), eluting with $\mathrm{PBS}$ at $4^{\circ} \mathrm{C}$.

\subsection{Determination of Calcein Loading and Releasing Amounts}

The amount of calcein trapped in the liposomes was measured according to the method of Oku et al. [35] or Sakai et al. [36] The membrane integrity of the liposome composed of DPPC containing 10 mol\% cholesterol and 
$4 \mathrm{~mol} \% \mathrm{SO}_{3}-\mathrm{CDC}_{16} \mathbf{1 0 - 1 2}$ after incubation in $\mathrm{PBS}$ at $37^{\circ} \mathrm{C}$ was evaluated by calculating the percentage of retained calcein encapsulated in the liposome. Initially, $0.1 \mathrm{mM}$ calcein in PBS was encapsulated in the. At different time intervals (up to $48 \mathrm{~h}$ ), the retention of calcein was estimated by mixing $20 \mu \mathrm{L}$ from each incubation tube with $2.0 \mathrm{~mL}$ of PBS (pH 7.4). A fluorescence spectrometer was used to measure the fluorescence intensity of calcein $\left(\lambda_{\mathrm{ex}}=490 \mathrm{~nm}, \lambda_{\mathrm{em}}=520 \mathrm{~nm}\right)$ before $\left(\boldsymbol{F}_{\text {total }}\right)$ and after $\left(\boldsymbol{F}_{\text {in }}\right)$ the addition of $10 \mathrm{mM} \mathrm{CoCl}_{2}$ solution (20 $\mu \mathrm{L})$. Then, $20 \%$ Triton $\mathrm{X}-100$ solution $(20 \mu \mathrm{L})$ was added to release the entrapped calcein, and the fluorescence intensity was measured again to determine the background fluorescence intensity $\left(\boldsymbol{F}_{q}\right)$. The trapped volume (\%) of calcein was calculated according to Equation (1):

$$
\text { Trapped volume }(\% \text { of total })=\frac{F_{\text {in }}-F_{q} \times r}{F_{\text {total }}-F_{q} \times r} \times 100
$$

where $r$ is the dilution factor due to the addition of the $\mathrm{CoCl}_{2}$ and Triton X-100 solutions. Herein, $r$ was 1.02.

\section{Results and Discussion}

\subsection{Synthesis of $\mathrm{SO}_{3}-\mathrm{CDC}_{16}$}

Figure 1 shows the synthetic method for $\mathrm{SO}_{3}-\alpha-, \beta$-, and $\gamma-\mathrm{CDC}_{16}$. First, selective silylation at the primary hydroxyl groups of $\alpha$-, $\beta$-, and $\gamma$-CD was carried out with tert-butyldimethylsilyl chloride (TBDMS-Cl) according to the method described by Ashton et al. [37] to give silylated $\alpha$-, $\beta$-, and $\gamma$-CD derivatives 1-3, respectively. Recently, it has been reported by Lesieur et al. that the esterification of CD derivatives using hexanoyl chloride in the presence of 4-dimethylaminopyridine (DMAP) results in over-acylation [28] [29]. In fact, the preparation of CD palmitate under this condition leads to asymmetric CD derivatives. Therefore, the use of palmitoyl anhydride could efficiently introduce a palmitoyl groups on the secondary face of CDs. The esterification of silylated CDs 1-3 was performed by adding two equivalents of palmitoyl anhydride and one equivalent of DMAP per hydroxyl group in dry pyridine. The reaction mixture was stirred for $48 \mathrm{~h}$ at $70^{\circ} \mathrm{C}$ and gave the desired CD palmitates 4-6. Next, desilylation occurred in the presence of boron trifluoride etherate $\left(\mathrm{BF}_{3} \cdot \mathrm{Et}_{2} \mathrm{O}\right)$ at room temperature for $6 \mathrm{~h}$. Desilylated derivatives 8 and $\mathbf{9}$ were purified by gel filtration chromatography with a Sephadex LH-20 column. Because the desilylated $\alpha$-CD derivative 7 was very moisture sensitive and more unstable than the other CD derivatives, it was evaporated under reduced pressure and used in the next step without further purification. Finally, sulfation of the free primary hydroxyl groups of the obtained CD amphiphiles 7-9 was

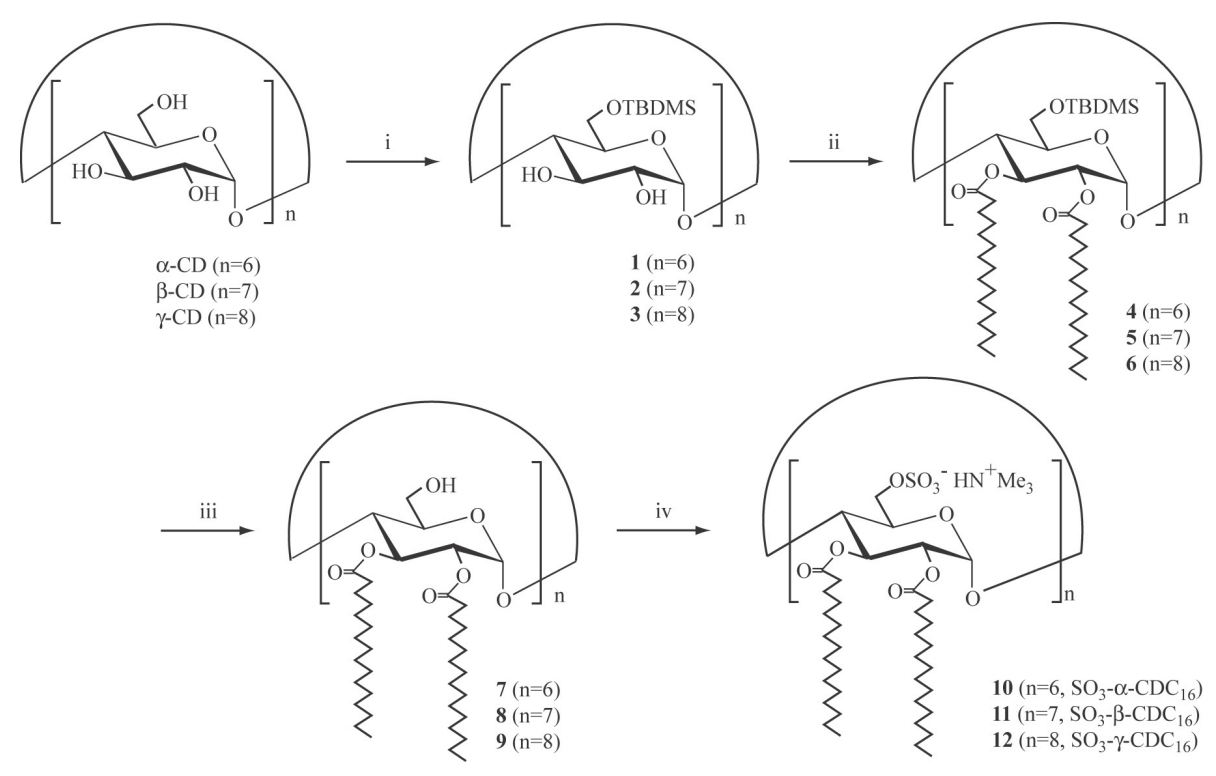

Figure 1. Synthesis of sulfated cyclodextrin amphiphiles. Reagents and conditions: (i) TBDMS$\mathrm{Cl} /$ pyridine, r.t., $8 \mathrm{~h}$; (ii) palmitoyl anhydride, DMAP/pyridine, $70^{\circ} \mathrm{C}$, $48 \mathrm{~h}$; (iii) $\mathrm{BF}_{3} \cdot \mathrm{Et}_{2} \mathrm{O} /$ $\mathrm{CH}_{2} \mathrm{Cl}_{2}$, r.t., $2 \mathrm{~h}$; (iv) sulfur trioxide trimethylamine complex/toluene-DMF (1:1), $100^{\circ} \mathrm{C}, 48 \mathrm{~h}$ for $10,80^{\circ} \mathrm{C}, 48 \mathrm{~h}$ for $11,12$. 
performed with sulfur trioxide-trimethylamine complex in a mixed solvent of toluene and DMF over $48 \mathrm{~h}$ under a nitrogen atmosphere, at $80^{\circ} \mathrm{C}$ in the case of the $\beta$ - and $\gamma$-CD amphiphiles and at $100^{\circ} \mathrm{C}$ in the case of the $\alpha$-CD amphiphile [38]. Purification using a Sephadex LH-20 column gave the desired $\mathrm{SO}_{3}-\alpha-, \beta$-, and $\gamma-\mathrm{CDC}_{16} \mathbf{1 0 - 1 2}$ bearing palmitoyl groups. A shift of $\sim 4 \mathrm{ppm}$ in the low magnetic field for the C-6 position in the ${ }^{13} \mathrm{C}-\mathrm{NMR}$ spectra showed that the primary hydroxyl groups were sulfated efficiently. The chemical structures of each CD derivative prepared here were elucidated using ${ }^{1} \mathrm{H}$ and ${ }^{13} \mathrm{C}$ NMR data and elemental analyses.

\subsection{Monolayer Behaviors of $\mathrm{SO}_{3}-\mathrm{CDC}_{16}$ at the Air-Water Interface}

The monolayer behaviors of $\mathrm{SO}_{3}-\mathrm{CDC}_{16} \mathbf{1 0 - 1 2}$ at the air-water interface were evaluated. The $\pi$ - $A$ isotherms recorded for 10-12 on pure water are shown in Figure 2. The isotherms indicated that each $\mathrm{SO}_{3}-\mathrm{CDC}_{16}$ forms a stable monolayer with a high collapse pressure $(40 \mathrm{mN} / \mathrm{m})$ at the air-water interface. The observed molecular areas at the collapse pressure were $2.45,2.98$, and $3.20 \mathrm{~nm}^{2}$ for $\mathbf{1 0}, \mathbf{1 1}$, and $\mathbf{1 2}$, respectively. The corresponding mean areas per single lipid chain were $0.204,0.213$, and $0.200 \mathrm{~nm}^{2}$ for $\mathbf{1 0}, \mathbf{1 1}$ and $\mathbf{1 2}$, respectively. These values are independent of the size of the cyclodextrin and close to the calculated hydrocarbon cross-sectional area of $0.200 \mathrm{~nm}^{2}$. This result indicates that the hydrophobic chains of $\mathrm{SO}_{3}-\mathrm{CDC}_{16}$ are well-packed and form dense monolayers. Similarly, the $\pi-A$ isotherms for the DPPC-cholesterol monolayer (mole ratio of 100:10) containing 10-12 (0 to $50 \mathrm{~mol} \%$ ) were investigated. Figure 3 shows the $\pi$ - $A$ isotherms at the air-water interface for DPPCcholesterol, 11, and their mixtures. The films containing between 4 and $8 \mathrm{~mol} \%$ of $\mathbf{1 1}$ formed liquid condensed films with high collapse pressures (max $65 \mathrm{mN} / \mathrm{m}$ ). This collapse pressure is close to the surface tension of water $\left(72.5 \mathrm{mN} / \mathrm{m}, 25^{\circ} \mathrm{C}\right)$. With more than $27 \mathrm{~mol} \%$ of 11-12, the collapse pressures of the mixed films were close

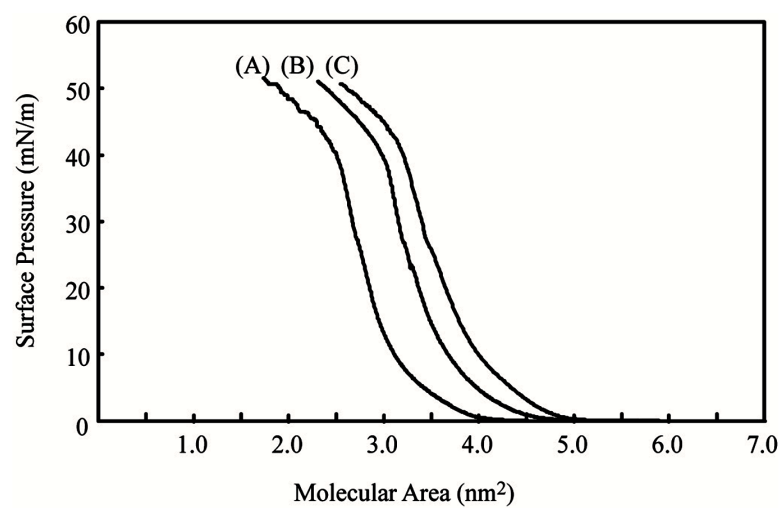

Figure 2. $\pi-A$ isotherms for Langmuir monolayers of $\mathrm{SO}_{3}$ $\mathrm{CDC}_{16}$ spread on the air-water interface; 10 (A); 11 (B) and 12 (C).

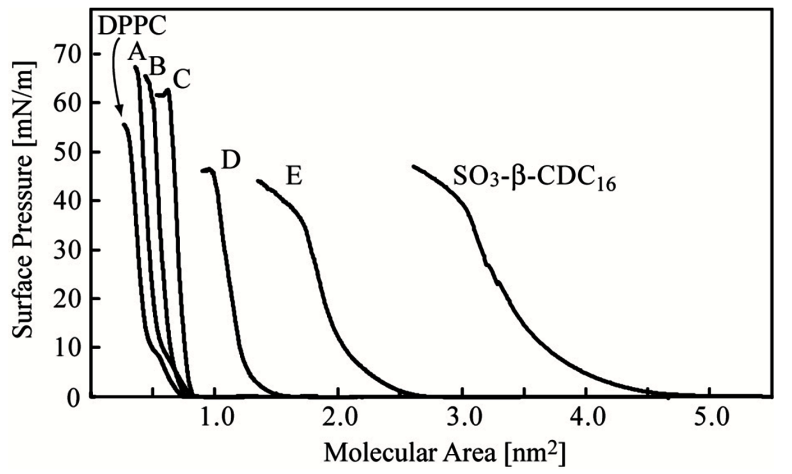

Figure 3. $\pi$ - $A$ isotherms for Langmuir monolayers of $\mathrm{SO}_{3}-\beta$ $\mathrm{CDC}_{16}$, DPPC-cholesterol and their mixtures containing $2 \mathrm{~mol} \%$ (A); $4 \mathrm{~mol} \%$ (B); $8 \mathrm{~mol} \%$ (C), $27 \mathrm{~mol} \%$ (D), and $50 \mathrm{~mol} \%$ (E) concentration of $\mathrm{SO}_{3}-\beta-\mathrm{CDC}_{16}$ spread on the air-water interface. 
to those of pure $\mathrm{SO}_{3}-\mathrm{CDC}_{16}(\sim 40 \mathrm{mN} / \mathrm{m})$, and the shape of the isotherms was similar. The molecular areas at a pressure of $30 \mathrm{mN} / \mathrm{m}$ are plotted as a function of $\mathrm{SO}_{3}-\mathrm{CDC}_{16}$ concentration in Figure 4. For most of the mixed ratios for each $\mathrm{SO}_{3}-\mathrm{CDC}_{16}$, the plots of the experimental molecule area at $30 \mathrm{mN} / \mathrm{m}$ were located on the ideal straight line. However, slight positive deviations from the ideal straight line were observed when the molecular fraction of $\mathrm{SO}_{3}-\mathrm{CDC}_{16}$ was less than $8 \mathrm{~mol} \%$.

The variation of the collapse pressures for 10-12 is shown in Figure 5. The collapse pressures showed maxima between 2 and $8 \mathrm{~mol} \%$. These results indicate that $\mathrm{SO}_{3}-\mathrm{CDC}_{16}$ forms stable monolayers at low concentrations by interacting with DPPC-cholesterol. A possible interaction between $\mathrm{SO}_{3}-\mathrm{CDC}_{16}$ and the matrix lipids is an electrostatic interaction between the positive charge of DPPC and the negative charge of the sulfonic moieties in $\mathrm{SO}_{3}-\mathrm{CDC}_{16}$. For example, 20 DPPC molecules surround a single $\mathrm{CD}$ derivative when the concentration of 11 is $4 \mathrm{~mol} \%$. In this work, good miscibility of the monolayers with up to $8 \mathrm{~mol} \%$ of $\mathbf{1 0}$ and $\mathbf{1 1}$ supports this suggestion. However, the decrease of collapse pressure at $8 \mathrm{~mol} \%$ of $\mathbf{1 2}$ may be caused by an insufficient number of DPPC molecules to encircle 12.

These results show that the mixed monolayers containing no more than 8 mol\% of $\mathbf{1 0}$ and $\mathbf{1 1}$ or less than 8 mol\% of $\mathbf{1 2}$ have higher collapse pressures than those of only DPPC-cholesterol or only $\mathrm{SO}_{3}-\mathrm{CDC}_{16}$, and therefore form more stable monolayers than $\mathrm{SO}_{3}-\mathrm{CDC}_{16}$ alone. The more stable mixed films are formed because there are a sufficient number of DPPC molecules to entirely surround $\mathrm{SO}_{3}-\mathrm{CDC}_{16}$. Thus, various activity measurements were performed with $4 \mathrm{~mol} \%$ of $\mathrm{SO}_{3}-\mathrm{CDC}_{16}$, as this is sufficient for DPPC to encircle $\mathrm{SO}_{3}-\mathrm{CDC}_{16}$.

\subsection{Morphological Analysis of Liposomes Composed of $\mathrm{SO}_{3}-\mathrm{CDC}_{16}$}

A morphological analysis of liposomes composed of $\mathrm{SO}_{3}-\mathrm{CDC}_{16}$ was performed by TEM after negative staining with a $2 \%$ uranyl acetate solution. First, the preparation of liposomes composed only of $\mathrm{SO}_{3}-\mathrm{CDC}_{16}$, in the

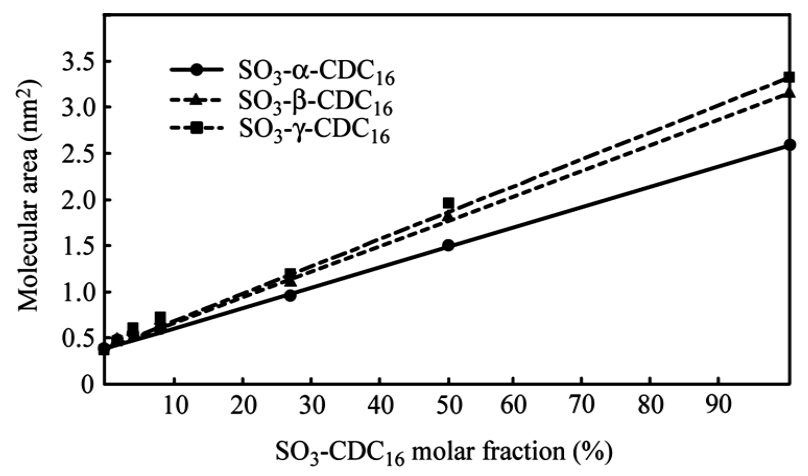

Figure 4. Relationships between $\mathrm{SO}_{3}-\mathrm{CDC}_{16}$ molar fraction at constant surface pressure $(\pi=30 \mathrm{mN} / \mathrm{m})$ and molecular areas $\left(\mathrm{nm}^{2}\right)$ for the mixed monolayers containing $4 \mathrm{~mol} \% \mathrm{SO}_{3}$ $\mathrm{CDC}_{16}$.

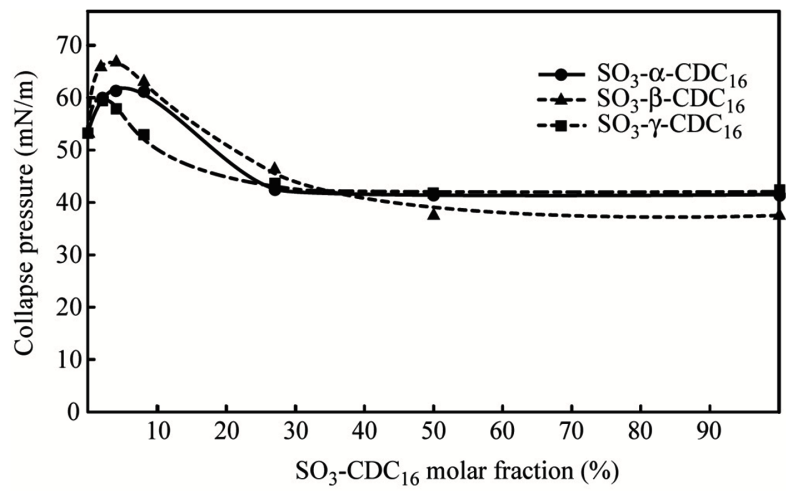

Figure 5. Relationships between $\mathrm{SO}_{3}-\mathrm{CDC}_{16}$ molar fraction and collapse pressure for mixed monolayers. 
absence of other amphiphiles was carried out by the reverse-phase evaporation method in water [39]-[41]. The TEM images of the liposomes are shown in Figure 6. The liposomes composed of $\mathbf{1 0}$ ( $\alpha$-liposome) were observed as spherical particles with a diameter of $\sim 150 \mathrm{~nm}$ at the maximum and tended to be smaller than those of the other $\mathrm{SO}_{3}-\mathrm{CDC}_{16}$ derivatives. The liposomes composed of $\mathbf{1 1}$ ( $\beta$-liposome) had a diameter of $\sim 350 \mathrm{~nm}$ at the maximum, whereas, the liposomes composed of 12 ( $\gamma$-liposome) had a diameter of $50-120 \mathrm{~nm}$ at the maximum. The $\gamma$-liposomes tended to aggregate with each other. However, these liposomes composed only of $\mathrm{SO}_{3}-\mathrm{CDC}_{16}$ could not be prepared in buffer with high ion concentrations. In order to make liposomes that would be stable in a living body as drug delivery carriers, $\mathrm{SO}_{3}-\mathrm{CDC}_{16}$ were introduced into liposomal membranes composed of phospholipids. Generally, liposomes composed of the $\mathrm{CD}$ amphiphiles were added to other amphiphiles, such as surfactants. Based on the results of the $\pi-A$ isotherms, monolayers containing $4 \mathrm{~mol} \%$ of $\mathrm{SO}_{3}-\mathrm{CDC}_{16}$ were the most stable. Therefore, liposomes with the same components are expected to be stable in buffer or other media. Figure 7 shows spherical particles composed of DPPC and cholesterol (100:10, mole ratio) containing 4 mol\% of $\mathrm{SO}_{3}-\mathrm{CDC}_{16}$. The liposomes containing $4 \mathrm{~mol} \%$ of $\mathbf{1 0}$ (4 mol\% $\alpha$-liposome) had diameters of around 50 - 250 $\mathrm{nm}$ with $400 \mathrm{~nm}$ at the maximum. In liposomes containing $4 \mathrm{~mol} \%$ of 11 (4 mol\% $\beta$-liposome), the diameters were about 50 - $400 \mathrm{~nm}$. Similarly, the size of the liposomes containing 4 mol\% of 12 (4 mol\% $\gamma$-liposome) had diameters of $80-500 \mathrm{~nm}$.

\subsection{Release of Calcein Encapsulated in Liposomes}

The fluorescence of calcein in buffered solution is reduced substantially and rapidly by the addition of $\mathrm{Co}^{2+}$ ions. In a solution containing calcein encapsulated in liposomes, the observed decrease in fluorescence intensity due to quenching of free calcein by $\mathrm{Co}^{2+}$ is completed within a few seconds of adding $\mathrm{Co}^{2+}$. The remaining fluorescence is not significantly affected by further additions of $\mathrm{Co}^{2+}$ ions. As revealed by a second decrease in fluorescence intensity, the subsequent addition of detergent allows $\mathrm{Co}^{2+}$ ions access to the calcein that was sequestered within the liposomes. The remaining fluorescence represents the sum of the fluorescence of the small amount of free calcein and the very low chelate. This can be reduced somewhat by using a very large excess of $\mathrm{Co}^{2+}$ ions, but the simplest procedure is to take the fluorescence after the detergent addition as the baseline. The fraction of the total volume that is trapped within the liposomes is given as the ratio difference between the initial and final values of fluorescence.

The retention time of vesicles encapsulating calcein was monitored after incubation in PBS for $48 \mathrm{~h}$ at $37^{\circ} \mathrm{C}$. Figure 8 shows the retention of calcein in the liposome composed of DPPC and cholesterol (100:10, mole ratio) with and without $4 \mathrm{~mol} \% \mathrm{SO}_{3}-\mathrm{CDC}_{16}$. More than $20 \%$ of the total calcein was released from the liposomes within $2 \mathrm{~h}$ at $37^{\circ} \mathrm{C}$; however, after that, the release rate was slow. The time at which half the total amount of
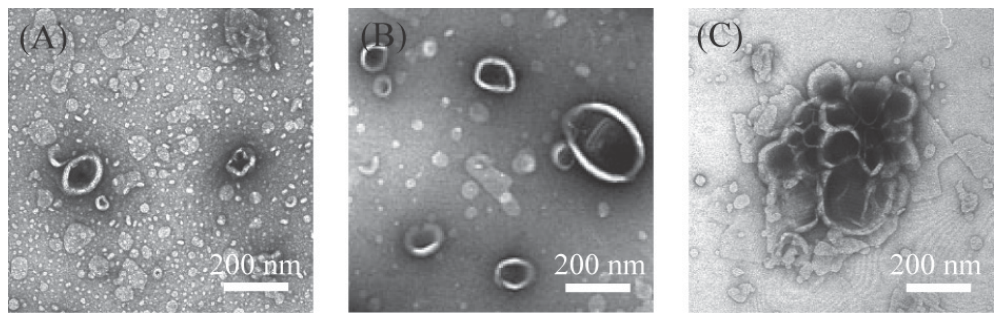

Figure 6. TEM images of liposomes composed only of $\mathrm{SO}_{3}-\mathrm{CDC}_{16}, \mathbf{1 0}$ (A); 11 (B); and 12 (C).
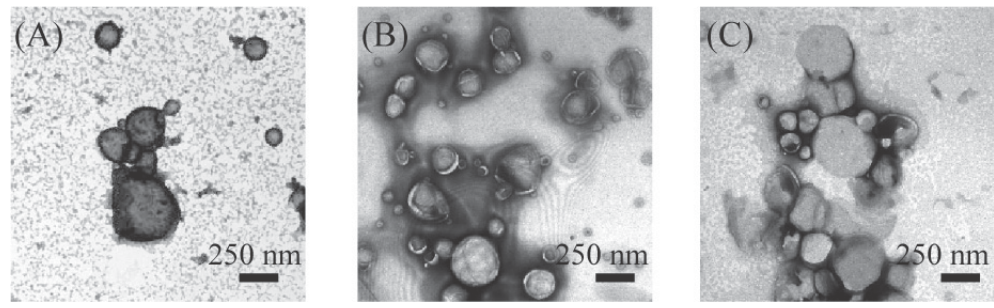

Figure 7. TEM images of liposomes of DPPC and cholesterol (100:10, mole ratio) containing 4 mol\% concentration of 10 (A); 11 (B); and 12 (C). 


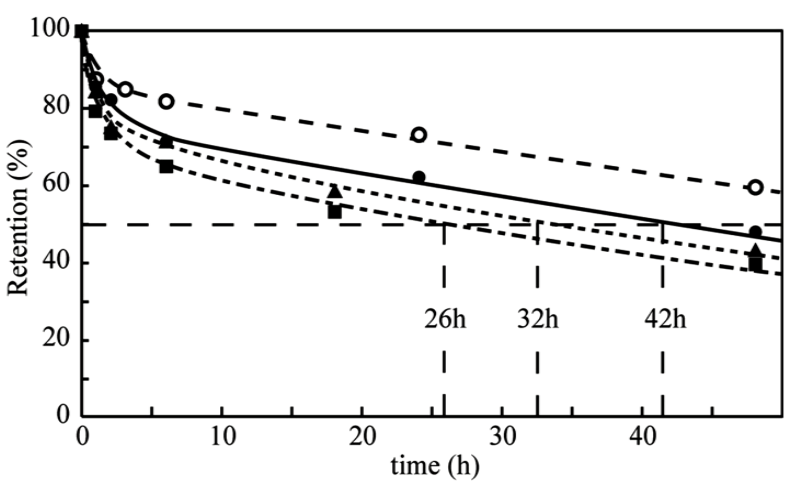

Figure 8. Release of encapsulated calcein from liposomes composed of DPPC and cholesterol containing $4 \mathrm{~mol} \% \mathrm{SO}_{3}$ $\mathrm{CDC}_{16}$ in PBS at $37^{\circ} \mathrm{C}$. Release amounts of the calcein were determined by fluorescence spectroscopy; liposomes composed of only DPPC-cholesterol $(\circ)$, containing $10(\bullet), 11$ $(\Delta)$, and $12(\boldsymbol{\square})$.

calcein was released was 26, 32, and 42 h for liposomes containing 10, 11, and 12, respectively. Even after 48 h, liposomes that did not contain $\mathrm{SO}_{3}-\mathrm{CDC}_{16}$ still retained $60 \%$ or more calcein. The liposomal membranes containing $\mathrm{SO}_{3}-\mathrm{CDC}_{16}$ are more stable than that consisting only of DPPC; however, the retention time of calcein encapsulated in liposomes containing $\mathrm{SO}_{3}-\mathrm{CDC}_{16}$ is shorter. The relation between liposomal membrane stability and retention capacity is not directly proportional. The release of molecules encapsulated in liposomes is related to the membrane mobility caused by the phase transition temperature of the compounds. The phase transition temperatures of DPPC, 10, 11, and 12 are $42^{\circ} \mathrm{C}, 41.0^{\circ} \mathrm{C}, 37.2^{\circ} \mathrm{C}$, and $36.6^{\circ} \mathrm{C}$, respectively. When the phase transition temperature is lower than the temperature of the buffered solution, the release of encapsulated calcein from the liposome is accelerated due to turbulence of the membrane. It has been suggested that the retention capability of the liposome could be controlled by changing the kind of CD.

\section{Conclusion}

$\mathrm{SO}_{3}-\mathrm{CDC}_{16}$ bearing sulfate groups and long acyl chains were synthesized efficiently using $\alpha$-, $\beta$-, and $\gamma$-CDs as a starting material. The obtained amphiphiles formed stable monolayers in the presence of DPPC and cholesterol at the air-water interface, and the collapse pressures were maximized at molar ratios of $\mathrm{SO}_{3}-\mathrm{CDC}_{16}$ lower than 10 mol\%. Moreover, liposomes with DPPC containing 4 mol\% $\mathrm{SO}_{3}-\mathrm{CDC}_{16}$ formed in PBS could be observed as vesicles with diameters of 350 - $500 \mathrm{~nm}$. The ability of these liposomes to release calcein was also investigated, and the liposomes containing $\mathrm{SO}_{3}-\mathrm{CDC}_{16}$ were clearly shown to release encapsulated calcein more easily than the liposomes consisting only of DPPC. It was suggested that the release rate depended on the phase transition temperature of the $\mathrm{SO}_{3}-\mathrm{CDC}_{16}$ derivative present in the liposome membrane. We are currently investigating the ability of the liposomes containing $\mathrm{SO}_{3}-\mathrm{CDC}_{16}$ as drug delivery carriers, and the results will be reported as soon as possible.

\section{Acknowledgements}

This work was supported by the Kansai University Grant-in-Aid of the Promotion and Upgrading of Education and Research, 2015, "Generation of bio-interactive polymers leading future-oriented medicals".

\section{References}

[1] Marcus, E.B. and Thorsteinn, L. (2007) Cyclodextrins as Pharmaceutical Solubilizers. Advanced Drug Delivery Reviews, 59, 645-666. http://dx.doi.org/10.1016/j.addr.2007.05.012

[2] Crini, G. (2015) A History of Cyclodextrins. Chemical Reviews, 114, 10940-10975. http://dx.doi.org/10.1021/cr500081p

[3] Szejtli, J. (1998) Introduction and General Overview of Cyclodextrin Chemistry. Chemical Reviews, 98, 1743-1753. http://dx.doi.org/10.1021/cr970022c 
[4] Loftsson, T. and Brewster, M.E. (2011) Pharmaceutical Applications of Cyclodextrins: Effects on Drug Permeation through Biological Membranes. Journal of Pharmacy and Pharmacology, 63, 1119-1135. http://dx.doi.org/10.1111/j.2042-7158.2011.01279.x

[5] Kha, A., Forgo, P., Stine, K.J. and D’Souza, V.T. (1998) Methods for Selective Modifications of Cyclodextrins. Chemical Reviews, 98, 1977-1996. http://dx.doi.org/10.1021/cr970012b

[6] Zhang, L., Zhang, Z., Li, N., Wang, N., Wang, Y., Tang, S., Xu, L. and Ren, Y. (2013) Synthesis and Evaluation of a Novel $\beta$-Cyclodextrin Derivative for Oral Insulin Delivery and Absorption. International Journal of Biological Macromolecules, 61, 494-500. http://dx.doi.org/10.1016/j.ijbiomac.2013.08.034

[7] Duchêne, D., Wouessidjewe, D. and Ponchel, G. (1999) Cyclodextrins and Carrier Systems. Journal of Controlled Release, 62, 263-268. http://dx.doi.org/10.1016/S0168-3659(99)00046-2

[8] Kassab, R., Félix, C., Parrot-Lopez, H. and Bonaly, R. (1997) Synthesis of Cyclodextrin Derivatives Carrying BioRecognisable Saccharide Antennae. Tetrahedron Letters, 38, 7555-7558. http://dx.doi.org/10.1016/S0040-4039(97)10033-8

[9] Oritiz-Mellet, C., Benito, J.M., García-Fernández, J.M., Law, H., Chmurski, K., Defaye, J., O’Sullivan, M.L. and Caro, H.N. (1998) Cyclodextrin-Scaffolded Glycoclusters. Chemistry-A European Journal, 4, 2523-2531. http://dx.doi.org/10.1002/(SICI)1521-3765(19981204)4:12<2523::AID-CHEM2523>3.0.CO;2-2

[10] Furuike, T., Aiba, S. and Nishimura, S.-I. (2000) A Highly Practical Synthesis of Cyclodextrin-Based Glycoclusters Having Enhanced Affinity with Lectins. Tetrahedron, 56, 9909-9915. http://dx.doi.org/10.1016/S0040-4020(00)00962-5

[11] Furuike, T., Sadamoto, R., Niikura, K., Monde, K., Sakairi, N. and Nishimura, S.-I. (2005) Chemical and Enzymatic Synthesis of Glycocluster Having Seven Sialyl Lewis X Arrays Using $\beta$-Cyclodextrin as a Key Scaffold Material. Tetrahedron, 61, 1737-1742. http://dx.doi.org/10.1016/j.tet.2004.12.035

[12] Roy, R., Hernández-Mateo, F. and Santoyo-González, F. (2000) Synthesis of Persialylated $\beta$-Cyclodextrins. Journal of Organic Chemistry, 65, 8743-8746. http://dx.doi.org/10.1021/j0005616l

[13] Ortega-Caballero, F., Giménez-Martinez, J.J. and Vargas-Berenguel, A. (2003) Diverse Motifs of Mannoside Clustering on a $\beta$-Cyclodextrin Core. Organic Letters, 5, 2389-2392. http://dx.doi.org/10.1021/ol0343941

[14] Muhanna, A.M.A., Ortiz-Salmerón, E., García-Fuentes, L., Giménez-Martinez, J.J. and Vargas-Berenguel, A. (2003) Synthesis of Peptide Dendrimers Based on a $\beta$-Cyclodextrin Core with Guest Binding Ability. Tetrahedron Letters, 44, 6125-6128. http://dx.doi.org/10.1016/S0040-4039(03)01432-1

[15] Mazzaglia, A., Angelini, N., Darcy, R., Donohue, R., Lombardo, D., Micali, N., Sciortino, M.T., Villari, V. and Scolaro, L.M. (2003) Novel Heterotopic Colloids of Anionic Porphyrins Entangled in Cationic Amphiphilic Cyclodextrins: Spectroscopic Investigation and Intracellular Delivery. Chemistry—A European Journal, 9, 5762-5769. http://dx.doi.org/10.1002/chem.200304861

[16] McCarthy, J., O’Neill, M.J., Bourre, L., Walsh, D., Quinlan, A., Hurley, G., Ogier, J., Shanahan, F., Melgar, S., Darcy, R. and O’Driscoll, C.M. (2013) Gene Silencing of TNF-Alpha in a Murine Model of Acute Colitis Using a Modified Cyclodextrin Delivery System. Journal of Controlled Release, 168, 28-34. http://dx.doi.org/10.1016/j.jconrel.2013.03.004

[17] Choi, S.H., Chung, J.W., Priestley, R.D. and Kwak, S.-Y. (2012) Functionalization of Polysulfone Hollow Fiber Membranes with Amphiphilic- $\beta$-Cyclodextrin and Their Applications for the Removal of Endocrine Disrupting Plasticizer. Journal of Membrane Science, 409-410, 75-81. http://dx.doi.org/10.1016/j.memsci.2012.03.037

[18] Liu, Z., Qiao, J., Tian, Y., Wu, M., Niu, Z. and Huang, Y. (2014) Polymeric Supra-Amphiphiles Based on Terminal Group Electrostatic Interactions: Fabrication of Micelles with Modifiable Surfaces. Langmuir, 30, 8938-8944. http://dx.doi.org/10.1021/la501936a

[19] Ji, R., Cheng, J., Yang, T., Song, C.C., Li, L., Du, F.S. and Li, Z.C. (2014) Shell-Sheddable, pH-Sensitive Supramolecular Nanoparticles Based on Ortho Ester-Modified Cyclodextrin and Adamantyl PEG. Biomacromolecules, 15, 35313539. http://dx.doi.org/10.1021/bm500711c

[20] Choisnard, L., Geze, A., Vanhaverbeke, C., Josias B.G. Yameogo, J.B.G., Putaux, J.L., Brasme, B., Jullien, L., Boullanger, S., Elfakir, C. and Wouessidjewe, D. (2011) Physicochemical Characterization of $\alpha$-, $\beta$-, and $\gamma$-Cyclodextrins Bioesterified with Decanoate Chains Used as Building Blocks of Colloidal Nanoparticles. Biomacromolecules, 12, 3031-3038. http://dx.doi.org/10.1021/bm2006664

[21] Abdelwahed, W., Degobert, G., Dubes, A., Parrot-Lopez, H. and Fessi, H. (2008) Sulfated and Non-Sulfated Amphiphilic- $\beta$-Cyclodextrins: Impact of Their Structural Properties on the Physicochemical Properties of Nanoparticles. International Journal of Pharmaceutics, 351, 289-295. http://dx.doi.org/10.1016/j.ijpharm.2007.09.035

[22] Chmurski, K., Bilewicz, R. and Jurczak, J. (1996) Monolayer Behavior of [6-Deoxy-6-S-phenyl]- $\alpha$-, $\beta$-, and $\gamma$-cyclodextrins at the Air-Water Interface. Langmuir, 12, 6114-6118. http://dx.doi.org/10.1021/la960205e 
[23] Kasselouri, A., Coleman, A.W. and Baszkin, A. (1996) Mixed Monolayers of Amphiphilic Cyclodextrins and Phospholipids: I. Miscibility under Dynamic Conditions of Compression. Journal of Colloid and Interface Science, 180, 384-397. http://dx.doi.org/10.1006/jcis.1996.0317

[24] Wazynska, M., Temiriusz, A., Chmurski, K., Bilewicz, R. and Jurczak, J. (2000) Synthesis and Monolayer Behavior of Amphiphilic Per(2,3-di-O-alkyl)- $\alpha$ - and $\beta$-Cyclodextrins and Hexakis(6-deoxy-6-thio-2,3-di-O-pentyl)- $\alpha$-Cyclodextrin at an Air-Water Interface. Tetrahedron Letters, 41, 9119-9123. http://dx.doi.org/10.1016/S0040-4039(00)01628-2

[25] Kawabata, Y., Matsumoto, M., Nakamura, T., Tanaka, M., Manda, E., Takahashi, H., Tamura, S., Tagaki, W., Nakahara, H. and Fukuda, K. (1988) Langmuir-Blodgett Films of Amphiphilic Cyclodextrins. Thin Solid Films, 159, 353358. http://dx.doi.org/10.1016/0040-6090(88)90648-7

[26] Parrot-Lopez, H., Ling, C.-C., Zhang, P., Baszkin, A., Albrecht, G., de Rango, C. and Coleman, A.W. (1992) SelfAssembling Systems of the Amphiphilic Cationic Per-6-amino- $\beta$-cyclodextrin 2,3-di-O-alkyl Ethers. Journal of the American Chemical Society, 114, 5479-5480. http://dx.doi.org/10.1021/ja00039a1001

[27] Tchoreloff, P.C., Boissonnade, M.M., Coleman A.W. and Baszkin, A. (1995) Amphiphilic Monolayers of Insoluble Cyclodextrins at the Water/Air Interface. Surface Pressure and Surface Potential Studies. Langmuir, 11, 191-196. http://dx.doi.org/10.1021/la00001a033

[28] Lesieur, S., Charon, D., Lesieur, P., Ringard-Lefebvre, C., Muguet, V., Duchêne, D. and Wouessidjewe, D. (2000) Phase Behavior of Fully Hydrated DMPC-Amphiphilic Cyclodextrin Systems. Chemistry and Physics of Lipids, 106, 127-144. http://dx.doi.org/10.1016/S0009-3084(00)00149-3

[29] Dubes, A., Degober, G., Fessi, H. and Parrot-Lopez, H. (2003) Synthesis and Characterisation of Sulfated Amphiphilic $\alpha-, \beta$ - and $\gamma$-Cyclodextrins: Application to the Complexation of Acyclovir. Carbohydrate Research, 338, 2185-2193. http://dx.doi.org/10.1016/S0008-6215(03)00356-2

[30] Falvey, P., Lim, C.W., Darcy, R., Revermann, T., Karst, U., Giesbers, M., Marcelis, A.T.M., Lazar, A., Coleman, A.W., Reinhoudt, D.N. and Ravoo, B.J. (2005) Bilayer Vesicles of Amphiphilic Cyclodextrins: Host Membranes That Recognize Guest Molecules. Chemistry—A European Journal, 11, 171-180. http://dx.doi.org/10.1002/chem.200400905

[31] Skiba, M., Nemati, F., Puisieux, F., Duchêne, D. and Wouessidjewe, D. (1996) Spontaneous Formation of DrugContaining Amphiphilic $\beta$-Cyclodextrin Nanocapsules. International Journal of Pharmaceutics, 145, 241-245. http://dx.doi.org/10.1016/S0378-5173(96)04756-4

[32] Ravoo, B.J. and Darcy, R. (2000) Cyclodextrin Bilayer Vesicles. Angewandte Chemie International Edition, 39, 43244326. http://dx.doi.org/10.1002/1521-3773(20001201)39:23<4324::AID-ANIE4324>3.0.CO;2-O

[33] Fatouros, D.G., Hatzidimitriou, K. and Antimisiaris, S.G. (2001) Liposomes Encapsulating Prednisolone and Prednisolone-Cyclodextrin Complexes: Comparison of Membrane Integrity and Drug Release. European Journal of Pharmaceutical Sciences, 13, 287-296. http://dx.doi.org/10.1016/S0928-0987(01)00114-2

[34] Sukegawa, T., Furuike, T., Niikura, K., Yamagishi, A., Monde K. and Nishimura, S.-I. (2002) Erythrocyte-Like Liposomes Prepared by Means of Amphiphilic Cyclodextrin Sulfates. Chemical Communications, 5, 430-431. http://dx.doi.org/10.1039/b110673b

[35] Oku, N., Kendall, D.A. and MacDonald, R.C. (1982) A Simple Procedure for the Determination of the Trapped Volume of Liposomes. Biochimica et Biophysica Acta, 691, 332-340. http://dx.doi.org/10.1016/0005-2736(82)90422-9

[36] Sakai, T., Kurosawa, H., Okada, T. and Mishima, S. (2011) Vesicle Formation in Mixture of a PEO-PPO-PEO Block Copolymer (Pluronic P123) and a Nonionic Surfactant (Span 65) in Water. Colloids and Surfaces A: Physicochemical and Engineering Aspects, 389, 82-89. http://dx.doi.org/10.1016/j.colsurfa.2011.08.046

[37] Ashton, P.R., Königer, R. and Stoddart, J.F. (1996) Amino Acid Derivatives of $\beta$-Cyclodextrin. Journal of Organic Chemistry, 61, 903-908. http://dx.doi.org/10.1021/j0951396d

[38] Baumann, R. and Rys, P. (1999) Metachromatic Activity of $\beta$-Cyclodextrin Sulfates as Heparin Mimics. International Journal of Biological Macromolecules, 24, 15-18. http://dx.doi.org/10.1016/S0141-8130(98)00058-0

[39] Szoka Jr., F. and Papahadjopoulos, D. (1978) Procedure for Preparation of Liposomes with Large Internal Aqueous Space and High Capture by Reverse-Phase Evaporation. Proceedings of the National Academy of Sciences of the United States of America, 75, 4194-4198.

[40] Rojanapanthu, P., Sarisuta, N., Chaturon, K. and Kraisintu, K. (2003) Physicochemical Properties of Amphotericin B Liposomes Prepared by Reverse-Phase Evaporation Method. Drug Development and Industrial Pharmacy, 29, 31-37. http://dx.doi.org/10.1081/DDC-120016681

[41] Lemos-Senna, E., Wouessidjewe, D., Lesieur, S. and Duchêne, D. (1998) Preparation of Amphiphilic Cyclodextrin Nanospheres Using the Emulsification Solvent Evaporation Method. Influence of the Surfactant on Preparation and Hydrophobic Drug Loading. International Journal of Pharmaceutics, 170, 119-128. http://dx.doi.org/10.1016/S0378-5173(98)00147-1 